\author{
В. П. Богданов \\ МГУ имени М. В. Аомоносова, Москва, Pоссия.vpbogdanov@gmail.com \\ ОХРАННЫЕ ФОРМУАЫ ХVI-ХІХ ВВ. \\ НА ЭКЗЕМП ЯРАХ СТАРОПЕЧАТНЫХ КИРИААИЧЕСКИХ ИЗААНИЙ: \\ ЭВОАЮЦИЯ И КААССИФИКАЦИЯ ТЕКСТОВ
}

\begin{abstract}
Под охранными формулами автор подразумевает речевые обороты, регламентирующие использование книг. Это составные части записей, фиксирующих вклады книг в церкви или монастыри, а также факты владения этими памятниками. Предметом анализа являются записи на старопечатных книгах XVI-XVIII вв. Автор разделил 334 записи на три группы по семантическому принципу: от наиболее нейтральных, содержащих только фразы типа «книгу хранить вечно и никто не изнесет», Ао наиболее эмоционально окрашенных, с использованием слов «анафема» и «проклят». Автор убедительно показывает, что пик их употребления приходится на 1630-е гг., однако отдельные записи встречаются вплоть до конца XIX в.

Ключевые слова: записи на книгах, старопечатные кириялические издания, охранные формуль, церкви, монастыри, владение
\end{abstract}

Проблема источниковедения записей на экземплярах старопечатных киримлических изАаний обсуждается в историографии постоянно (см. об этом: [Поздеева, 1978; Шустова] и Ар.). Исследователей интересует как введение в научный оборот новых текстов, так и выработка методики их анализа. Автор предлагаемой статьи пошел по пути созАания базы Аанных ([БогАанов; БогАанов, Высоцкий] и Ар.).

На этот раз предметом исследования стали те записи, которые содержат охранные формулы. За последними в историографии закрепилось наименование «формулы проклятия» (см., например: [Поздеева, 1987; Шапимова]). ОАнако оно не совсем отражает их суть, о чем будет сказано ниже.

К охранным формулам следует отнести определенные фрагменты текстов, обозначающих вклады книг в церкви, а также факты вмадения ими церковными библиотеками ими частными мицами, содержащие запреты на какое-либо несанкционированное использование этих книг: кражу, заклаА, порчу и т. А. Уже наиболее ранняя запись, фигурирующая в базе Аанных, содержит охранную формулу: « Аета 7084го (1575/1576) положена бысть сия книга Евангилие тетри (!) на престол во храм Ивана Предоотечи (!) да Николы чюдотворца на вол [ж] ско[и] берег рабъ Божии Никифоръ Григорьев сынъ, а прозвище Богдан Самария. А не вцастоватися тою книгою ни попу, ни диякону, ни прихожаном, ни детем моим. А потписал сынъ его Григореи своею рукою» ${ }^{1}$. Речевой оборот «не властоватися тою книгою ни попу, ни диякону, ни прихожаном, ни детем моим» и следует считать охранной формумой.

В основу настоящей статьи мегли записи на книгах, опубликованные в каталогах описаний экземпляров старопечатных киримлических изданий, хранящихся в Научной библиотеке МГУ, а также в региональных собраниях: Тверской, Пермской, Ярославской областей, собрания Троице-Сергиевой мавры и музея Кижи; нескольких старообрядческих общинных библиотек. Итого, 14 каталогов (все они выпущены поА эгидой МежкафеАральной археографической

1 Евангелие. Вильно, 1575; Ярославль, 2004. № 8. Аалее Аля удобства ссыцки на запись будут оформляться по следующей схеме: название книги, место и год ее издания, а также краткое обозначение каталога и номер в нем. 
маборатории МГУ), содержащих описания 5102 экземпмяров изАаний 1492-1800 гг. В Аанной статье цитируются записи восьми катаногов ${ }^{2}$.

Выявлено 334 записи, содержащие какие-либо ограничения по использованию книг и сумящие наказание за нарушение запрета. Слова «проклятие» или «анафема» встречаются 81 раз, то есть только в 24 \% случаев. По этой причине в статье используется именно термин «охранные формулы», а не «формулы прокмятия».

210 записей имеют точную (впиоть до гоАа) Аатировку и охватывают период с 1575 по 1898 г. В суммированном виде некоторые данные приведены в таблицах 1-2 Приложения.

В рамках данной статьи сосредоточимся на вопросах эволюции, распространения и классификации этого типа исторических текстов. Такие важные вопросы, как социальный состав инициаторов записей, требуют отдельного дополнительного исследования.

\section{Методика работы}

О структуре базы данных и преАставительности полученной исторической выборки автору уже приходилось писать [БогАанов, Высоцкий]. В Аанном скучае остановимся кишь на методах анализа информации записей, содержащих охранные формулы.

Из общего массива были выявлены записи, содержащие запреты в использовании книг и описания наказаний за противоправные действия (обозначаются такими речевыми оборотами, как «а кто сию книгу... », «и Ао той книги никому дема нет... » и т. А.). Кроме того, большинство записей подобного плана содержат некоторые угрозы типа отсутствия благодати на том, кто нарушит запреты. Часто используются такие слова и сочетания, как «анафема», «будет прокмят», «не минует Божьего суда».

Поскольку в случаях, где это возможно, записи в самой базе Аанных датированы и привязаны к регионам, то выборка из записей с охранными формулами уже изначально содержит эти соотнесения с хронологией и географией.

ИногАа географическая мокализация очевидна: в записи указан населенный пункт, уезА и проч. Но иногда установмение региона требует определенной дополнительной работы. Так, Аля географической мокализации записи 1582 г. с охранной формулой пришмось привмечь и Аругие записи на экземпмяре $\mathrm{e}^{3}$. В некоторых скучаях география устанавливается по языку записей. Использование слов «року» вместо «года», «жонка» вместо «жена» и проч. позволяет утвержАать, что запись сАелана на территории Украины или Белоруссии. ИногАа фигурирует человек, про которого известно, что он точно проживал в Аанном регионе.

\footnotetext{
2 Поздеева И. В., Кашкарова И. А., Аеренман М. М. Каталог книг киримиической печати XV-XVII вв. в Научной библиотеке Московского университета. М., 1980 (Аалее - МГУ, 1980); Поздеева И. В., Ерофеева В. И., Шитова Г. М. Киримлические издания. XVI век - 1641 г.: Находки археографических экспедиций 1971-1993 годов, поступивших в научную библиотеку Московского университета. М., 2000 (Аалее - МГУ, 2000); Киримлические изАания в хранилищах Тверской земли (XVI век - 1725 гоА). Каталог. Тверь, 2002 (Аалее - Тверь, 2002); Киримлические изАания XVI-XVIIвв. в хранилищах Пермской области. Каталог.Пермь, 2003 (Аалее-Пермь, 2003); Киримиические издания Ростово-Ярославской земли (1493-1652 гг.). Каталог. Ярославль; Ростов, 2004 (Аалее - Ярославль, 2004); Киримлические изАания XVIII века в хранилищах Пермского края. Каталог. Пермь, 2008 (Аалее - Пермь, 2008); Кирилмические издания Ростово-Ярославской земли (1653-1700 гг.). Каталог. Ярославль; Ростов, 2009 (Аамее - Ярославль, 2009); Аадыкин А. В. Описание одной из библиотек конфессиональной общины Верхокамья (конец XX в.) // Материалы к истории старообрядчества Верхокамья: по итогам комплексных археографических экспедиций исторического факультета МГУ имени М. В. Аомоносова: сборник документов. М., 2013. С. $133-182$ (Аалее - Верхокамье, 2013).

${ }^{3}$ Евангелие учительное. Вильно: Печатник В. М. Гарабурда, ок. 1580; МГУ, 2000. № 18. Исходя из того, что книга была выпущена в Вильно, а вторая по хронологии запись (XVIII в.) на экземпляре оставлена «могилевцем», то есть жителем г. Могилева или его окрестностей, можно преАположить, что книга по крайней мере Ао XVIII в. не покиАала территории Западной Руси. Соответственно и запись 1582 г. сАелана там же.
}

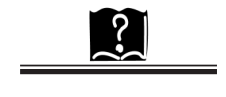


Например, фамилия соликамских купцов Ростовщиковых позволила отнести саеланный ими вклаА именно к Пермскому краю4.

В результате уАалось выявить 10 географических центров книжной культуры: несколько близко расположенных Аруг к Аругу населенных пунктов, сведения о которых встречаются в записях, были объединены в более крупные географические единицы.

Такие показатели, как Ааты, географические привязки, разные типы охранных формул, позволяют проводить сопоставцения и интерпретацию полученных результатов.

\section{Разновидности охранных формум}

При анализе текстов, содержащих более или менее стандартные формулировки, возникает желание применить «формулярный анализ» (как это блестяще продемонстрировано C. М. Каштановым на актовом материале [Каштанов]). В нашем случае вариативность текстов Аостаточно велика, а сами тексты слишком небольшие по объему, чтобы применять к ним столь трудоемкую методику.

В связи с этим было решено попробовать классифицировать записи с охранными формулами исходя из их содержания. Критерием стала степень радикальности запретов и угроз, встречающихся в формулах. Самые «мягкие» - это записи, где содержатся только фразы: «книгу хранить вечно и никто не изнесет», «до книги никому дела нет». Самые сильные по эмоциональной окраске - записи, гАе совместно встречались слова «анафема» и «проклят».

В результате все записи подразделяются на три большие группы.

Первая группа: наказ на сохранение книги в церкви на прежнем месте и запрет на ее перенос. К ним относятся записи с формулировками типа «Аа той книги никому дека нет», «не властоватися тою книгою никому» и Ар. Пример - приведенная в начале статьи наиболее ранняя запись Богдана Самарии. Аналогична запись 1596 г. некоего Клима Есипова, который писал: «... тех книг Авух Охтаев из монастыря не продать не променять никому, держать их в монастыре у Ивана Богослова покаместь обител стоит» ${ }^{5}$. Аата второй записи Есипова утрачена, и в каталоге она не Аатирована, однако можно преАположить, что она сАелана в тот же гоА.

Налицо запрет на какое-либо движение книги, но без угрозы наказания за нарушение условий хранения. СуАя по отсутствию специфических терминов, характеризующих западнорусский диалект, запись сделана в России: при этом имеется вероятная привязка к региону - монастырь Иоанна Богослова, одна из святынь г. Чердыни.

К этой же категории «мягких» запретных формул отнесены и угрозы мегкого наказания. Так, выявлен один случай, когАа в качестве угрозы выступает гражАанский суА: «Сия книга глаголемая кормчая строителя и Михаиловския (?) игумна белецкаго Герасима куплена въ 734м году Февраля 2 ден на свои собственные денги и кто украдетъ ея повиненъ гра[ж] Аанскому суАу и Аопросу ${ }^{6}$, и один скучай, когАа - штраф: «... кто заложитъ или продастъ, и то ему бы Аоправить 4 рубли с полтиной»?

Таковых записей выявлено 129; точные даты (известны в 79 случаях) охватывают периоА с 1575 по 1898 г. Может смущать крайняя дата - 1898 г. ОАнако предыдущая дата Аатированной записи - 1822 г. (она принадлежит ко второму типу), а еще более ранняя - 1802 г. То есть XIX в., о чем будет сказано ниже, - время, когАа традиция использования охранных формул (по крайней мере, на экземплярах старопечатных киримлических изданий) ушла в прошлое.

${ }^{4}$ Стефан (Яворский). Камень веры. М.: Синодальная типография, 10.1728; Пермь, 2008. № 110.

${ }^{5}$ Октоих. Ч. ІІ. М.: Печатник Анароник Тимофеев Невежа, 1594; Пермь, 2003. № 8.

${ }^{6}$ Кормчая (в переделанном виде). М.: Печатный Авор, 1653; МГУ, 1980. № 495.

${ }^{7}$ Апостол. М.: Печатный Авор, 1633; МГУ, 2000. № 253.

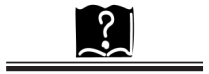


Вторая группа: Аетальное перечисление запретов несанкционированного использования книги и (ими) угроза за несоблюдение запрета. В качестве угрозы может выступать: «тягость церковная», «Божий суА».

Первая запись этого плана: « $е$ ета 7091го (1582/1583) при деръжаве государя [ц]аря и великаго князя Ивана Василевича всеа Русии и при благоверном царевиче князе ФеАоре Ивановиче и преосвещенном Аионисие митрополите положил сие Еvангелие на престол оу Николы чюдотворца в Новои Русе рабъ Божии Иван Васильев сынъ по своих родителех, поминати раба Божия Василья, Анну, Антония оубиеннаг[о], Аевицу Марину, Прокопия, Григория, Ивана. А кто сие Еvангелие отнесет от Николы и таму Богъ судитъ. И при жывоте Иванове за них замолити и за его жену УАиту, а по смерти их поминати и их родителеи» ${ }^{\circ}$. Мы видим указание на то, что книга была положена в северных пределах русского государства Новой Руссе.

Вторая запись более категорична: « $е$ ета 7090-го (1582) положил сию книгу толковое Евангилие в храм... (срезано) Иван Амитреев сынъ Бохтин... (срезано) да Аал сию книгу по своеи Ауши и по своим родителем. А хто с[ию] книгу из сего храма снесет или корысть получает и он разсудится са мною преА Спасом и судья ему Богъ Исусъ Христосъ.... В записи содержится не только запрет на «изнесение» из храма, но и санкция за «корысть»: «рассудится» переА Богом. Причем вынос из храма и «корыствование» (видимо, продажа, обмен и проч.) явно противопоставляются - межАу ними союз «ими». То есть наиболее страшным преступлением явмяется именно извлечение выгоды.

Приведем еще несколько примеров.

Вот, в частности, пример перечисления того, что нельзя Аелать с книгой: «7162-го гоАу (1653/1654) Аал сию сию (!) книгу глаголемую Трефолои в Ростове в церковь святых апостолъ Петра и Павла москвитин Василеи Иванов сынъ Печенка по своеи душе и по своих родителях (!) в вечныи поминок, а никому наА сею книгою хитрости никакои не учинит, из сее церкви ни продат, ни заложит» ${ }^{10}$.

Еще одна запись - обещание «церковной тягости» за несанкционированное использование книги: « 7200 году (1692) месяца июня въ 10 [Аень] сию печатную книгу Минею месяцъ ианнуарии подамъ въ Ярославмь в церковь пречистые Богородицы Казанские в девичь монастырь ярославець посадцкои человекъ Иоанъ Назарьевъ сынъ Мякушкинъ по обещанию своему в вечное помяновение по схимнице Анастасии и Аля своего душевнаго спасения. И быт сеи книге в тои церкви вечно неотъемлемо и никому не владети и не продати не заложит, а буде кто сею церковною книгою станет владет ими продастъ и Аа будет на немъ церковная тягость, якоже святии отцы заповедали, Аа им отсудитися на Страшном Христове суде $\gg^{11}$. Интересно, что Иван Назарьев сын Мякушкин совершил три вклада в Казанский монастырь и на всех трех имеется анамогичная запись.

Ко второму типу охранных формул отнесена и поэтичная формула, введенная в научный оборот И. В. Поздеевой [Поздеева, 1987]:

«Кто помыслит продат,

тому пропасть

а кто помыслит заложит

тому головой наложить (голову положить? - aвm.) $\gg^{12}$.

\footnotetext{
${ }^{8}$ Евангелие. Вильно: Печатник М. Т. Мстиславец, 1575; Ярославль, 2004. № 7.

9 Евангелие учительное. Вильно: Печатник В. М. ГарабурАа, ок. 1580; МГУ, 2000. № 18.

10 Трефологион, третья четверть (март - май). М.: Печатный Авор, 1638; Ярославль, 2004. № 343.

${ }^{11}$ Минея скужебная, январь. М.: Печатный Авор, 1691; Ярославль, 2009. № 643.

12 Апостол. М.: Печатный Авор, 1635; МГУ, 1980. № 235. Трактовка смысла слова «наложить» принадмежит

И. В. Поздеевой.
}

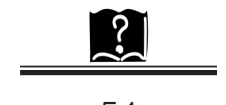


Записей, подобных вышеприведенным, выявмено 123; точные даты (известны в 88 скучаях) охватывают период с 1582 по 1822 г.

Третья группа: послание прокмятия. Это записи, содержащие такие слова, как «прокмятие», «анафема» или оба сразу.

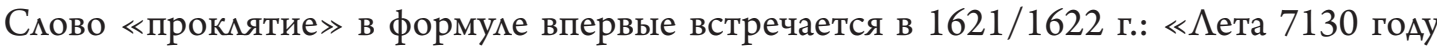
(1621/1622 г.) книгу охтаии положили в церков Рожество Христово игуменъ Еуфимеи Аа Иван Яковлев сынъ $\Lambda$ апин, а хто сию книгу дерзнет продат или заложи[ть] Аа будет проклят. Подписаи игумен Еуфимеи своею рукою» ${ }^{13}$. Слово «анафема» впервые зафиксировано раньше - в 1602 г. Запись (сохранилась фрагментарно), слеланная в Смоленске или ближайших окрестностях неким мещанином БогАаном (в крещении Сидором), более категорична: «николи не порушъно... храма Успения владычеца нашея Богородица замъку... подъ анафемою и отлучениемъ в день второго пришествия от всих веръных избранных Божиих

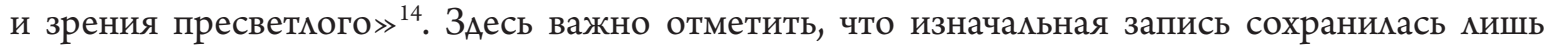
Ао указания на место, где стоит храм. Уже слово Смоленск написано Аругим почерком. То есть сама охранная формула дописывалась в то время, когда Смоленск был занят поляками. Отсюда и указание: «при державе государа коромя Жыкъмонта ... за архиепископа Ипатия Потея».

Совместно слова «прокмятие» и «анафема» встречаются 20 раз. Впервые в 1638 г.: «... мещане каменецкии подАании его мосце (!) пана Потоцкого старосты Галицкого воеводи Бреславскаго купили сию книгу на имя Ейангелие и з отцемъ Тимофиемъ за зАравие свое и за отпущение грехов и придали еи ко храму Благовещания Пресвятои Богородици. А хто би еи мал отАалити от престолу Благовещения или Аияк или Аиякон или поп на них прокмятие анафема року божего 1638 месяца априля Аня 25» ${ }^{15}$. ПослеАний раз сочетание Авух слов, обозначающих сильнейшее наказание, встречается в 1755 г.

Записей третьего типа выявмено 82; точные даты (известны 26) охватывают периоА с 1602 по 1777 г.

Три типа охранных формул сложились к 1610-м гг. При этом наиболее радикальная разновидность фиксируется спустя 27 мет после первой и 20 мет после второй. Аалее три разновидности охранных формул бытовали практически парамлельно.

Рассмотрим наиболее ранние Аатированные записи с охранными формулами, чтобы проследить их генезис. При этом, в основном (кроме специально оговоренных случаев) Амя краткости, будем цитировать только формулы, а не записи целиком.

Записи XVI в. и 1602 г. мы уже рассмотрели. Следующие по хронологии - Аве записи 1608 г. Из них оАна сАелана в России, вторая - на Украине.

В первой записи (вклал Олифера Июдина сына Пастухова в церковь «Богоявления Христова и Введения пресвятеи Богородицы и въ Екатерины Христовы мученици») сказано, что «кто изъ божественныя церкви без благословления вынесет сию книгу и мы разсудимся на страшном суде ${ }^{16}$. То есть за ослушание виновнику грозит держать ответ на Страшном суде, оАнако сама охранная формула достаточно мягкая и вынос книги возможен.

Запись, сделанная на Украине, содержит похожее перечисление, но более категорична: «Еже аще бы кто дерзнулъ оттворити аще ки ктиторъ или попъ причетникъ или тать или ин кто ж человек, таковая каждая особа суперника Аа имает пречистую Божию Матерь в день

\footnotetext{
13 Октоих, части I и II. Ч. ІІ: гласы 5-8. М.: Печатный Авор, печатники Н. Ф. Фофанов и П. В. Федыгин, 1618; Ярославль, 2004. № 82.

${ }_{14}$ Апостол. ИзА. 3-е. Вильно, после 1595; МГУ, 2000. № 46.

${ }^{15}$ Евангелие (с сигнатурами). Вильно: Типография А. и К. Мамоничей, 1600; МГУ, 2000. № 64.

16 Триодь постная. М.: Печатник А. Т. Невежа, 1607; МГУ, 2000. № 83.
}

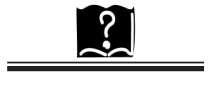


страшного въдания правеАнаго судии Христа Спаситемя нашего ${ }^{17}$. Примечательна угроза, что те, кто ослушался указанного в записи запрета, на Страшном суде в качестве соперника будут иметь Богородицу. Это связано, видимо, с тем, что вклад был совершен «къ храму Покрову... ВАадычица нашея Богородица приснодевы Марии».

Процитированные выше записи относятся к формулам второго типа.

В записи 1611 г. могикевского жителя сказано: «А хто смеет без благословения и позволения настоятелева сию книгу глаголемую Устав Око церковное из храму церкви Богоявъмения Господа Бога и Спаса нашого Исуса Христа изнести ... (срезано) на страшном суде ${ }^{18}$. Аругая запись (Симонова монастыря старца Сергия) того же года содержит похожую

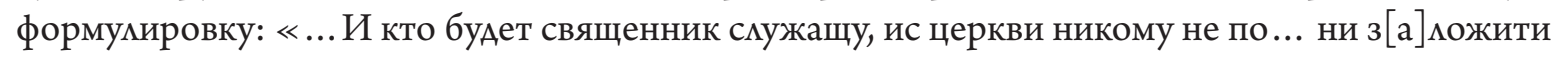
ж поА заклаА ни в ыную церковъ не переносити, ни учениковъ по неи не учити. И которои священник или дияк церковныи или инъ продастъ книгу сию или поА заклаА заложит или учеников по неи станет учити и мне с ним судится на господнемъ нашимъ Исусовомъ Христовомъ пришествии ... $\gg^{19}$. Формулы обеих записей могут быть отнесены ко второму типу.

Следующая по хронологии запись, 1612 г., сделана в России и очень кратка. Старец Мисаил при вкладе книги в церковь Рождества Иоанна Предтечи и Николе чюдотворцу в Ярославле указал: «а не властвоватися сею книгою ни попу, ни Аьякону не прихожан $[$ а $] .. . \gg^{20}$. Формука относится к первому типу.

В апреле 1613 г. видные деятели Смутного времени купцы Аыткины, совершившие вклаА «въ Ярославле Поволскомъ на посаде в домъ пречистые Богородици честныя и славныя ея Похвалы і великих страстотерпцев Аимитрия и Георгия», оставили мишь указание «и по своих родителех безотымочно во веки» ${ }^{21}$.

Запись 1613 г. князя Р. П. Пожарского о вкладе «в Стародубе Ряполовском в село Троецкое»: «а хто сию книгу возметъ от великого чюдотворца Николы и тот бvдет анафема ${ }^{22}$. Мы видим, что, хотя и нет угрозы Страшного суда, но впервые звучит слово «анафема». Это означает, что переА нами формула третьего, наиболее категоричного, типа.

В записи 1614 г., которую составили «Антипа прозвище Гус [c] с <ы>ном своим с Козмою», сказано, что книга вложена к «Аазаревоу Воскресеню... во граде во Твери на посаде» и Ао нее никому «Аела нет ни роду моему ни племяни» ${ }^{23}$. То есть переА нами формула первого типа, созданная в выделенном Западном регионе.

Запись 1618/1619 г. принадлежит известному политическому деятелю начала XVII в. - Аьяку С. Ю. Раманчюкову. Примечательно, что вклаА скреплен еще более нейтральной формулой: «А тем Евангелием никому не покорыстоватца» ${ }^{24}$.

Итак, четыре из 16 наиболее ранних записей (если брать еще и выше разобранные записи XVI в., включая Аве записи Козьмы Есипова) отличаются более жесткими формулировками, нежели остальные. Все четыре сделаны на Западе (Смоленск) и Юго-Западе (Белоруссия, Украина) русского православного мира.

Уже исходя из этого можно преАположить, что мы имеем Аело с разными региональными традициями. В конце XVI - начале XVII в. охранные формулы, бытовавшие на территории Российского государства, были более мягкими по сравнению с теми формулами, которые

\footnotetext{
${ }^{17}$ Евангелие учительное. Кримос, 1606; МГУ, 2000. № 79.

18 Устав (Око церковное). М., 1610; МГУ, 2000. № 100.

${ }^{19}$ Минея общая. М.: Печатник А. Т. Невежа, 1600; МГУ, 2000. № 65.

${ }^{20}$ Октоих. Ч. ІІ. М.: Печатник А. Т. Невежа, 1594; МГУ, 1980. № 46.

${ }^{21}$ Триодь Постная. М., 1607; Ярославль, 2004. № 66.

${ }^{22}$ Минея служебная, октябрь. М.: Печатник А. Т. Невежа, 1609; Ярославль, 2004. № 71.

${ }^{23}$ Евангелие. Вильно: Печатник П. Т. Мстиславец, 1575; МГУ, 1980. № 23.

${ }^{24}$ Евангелие. М.: Печатный Авор, Нижний НовгороА, 1613(?); Ярославль, 2004. № 90.
}

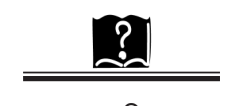


бытовали на Украине и Белоруссии. Потом, видимо, мода на более пространные и категоричные формулы распространилась (через западные города России, такие как Смоленск, Тверь) и в России.

Приведем также три записи конца XVIII - начама XIX в.

Охранная формула 1793 г. гласит: «Успения пр <есвя >стой в <а $>$ А $<$ І $>$ ч $<$ и $>$ ци нашей Б<огороди>ци и присно $\mathrm{M}<\mathrm{a}>$ рие аби не била отАалена сия книга глаголемаи кмючъ поА проклятием с<вя >тих от <е $>$ ц ... ${ }^{25}$. Последние Авезаписи сопровожАаютвкмадыкамязинского купца Василия Красильникова в церковь Николая Чудотворца: «аще кто сию книгу отметь от церквы святои то суди его госпоть бохъ въ будущемъ веке» $(1802 \text { г. })^{26}, \ll \ldots$ а ежели кто оную книгу возметъ от той церкви, то его судить Бохъ в будущемъ веке... » $(1822 \text { г. })^{27}$. Запись 1793 г. может быть отнесена к третьему типу, 1802 и 1822 гг. - ко второму.

Мы виАим, что позАние записи по своему характеру практически не отличаются от ранних.

В заключение раздела следует обратить внимание на то, против чего выступали вкладчики.

На первом месте стоит, как уже видно из приводившихся цитат, «изнесение» и извлечение «корысти» (продажа, заклад и проч.).

Кроме того, в охранных формулах встречается запрет на то, чтобы книгу возили по разным местам («а по деревням не таскат» ${ }^{28}$ ). Иногда вкладчик пишет, что книгу надо «беречи и воскомъ не искапати... $\gg^{29}$, «свящею не каплите, со всяким береженьемъ блюдите... $\gg^{30}$. На вкладной записи царя Михаила Федоровича (единственной с охранной формулой) значится,

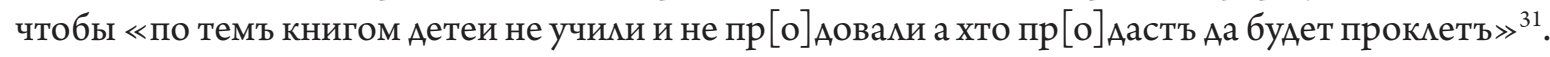

\section{Наблюдения за охранными формуками на рукописях}

Охранные формулы появляются довольно рано на рукописных памятниках. Причем часто их ставят уже сами писцы - создатели рукописей, указывая цели и заАачи их написания: такойто человек заказал Аанную рукопись Аля такой-то церкви (наиболее наглядно это преАставлено в публикации А. С. Усачева $\left.{ }^{32}\right)$.

Соответственно, обращение к записям с охранными формулами на рукописях позволяет проследить генезис Аанного явления. ОАнако мы обратились к рукописям уже после получения определенной картины на материале старопечатных книг, которого по определению (исхоАя из числа печатных книг) больше. Аанный опыт носит характер проверки гипотезы. Были взяты два каталога, к созАанию которых также были причастны археографы МГУ: тверского 33 и пермского ${ }^{34}$ собраний.

Из 155 рукописей XIV-XVII вв., фигурирующих в Авух каталогах (90 в Тверском и 65 в Пермском), охранные формулы содержат 12. Точные даты охватывают период с 1486

\footnotetext{
${ }^{25}$ Иоанникий Гамятовский. КАюч разумения. Аьвов, 1663; МГУ, 1980. № 543.

${ }^{26}$ Евангелие учительное. Евье: Типография Братства Св. Ауха, 1616; МГУ, 1980. № 99.

27 Служебник. ИзА. 2-е. М.: Печатный Авор, 1656; Тверь, 2002. № 110. Интересно, что книги, находившиеся в церкви Николая Чудотворца, имели разную судьбу. ОАна, видимо, попала в хранилище Калязинского монастыря и оттуда - в Тверской музей (ныне Тверской государственный объединенный музей), а Аругая - в библиотеку Института философии, митературы и истории, а затем - в обменный фонА библиотеки МГУ.

${ }_{28}$ Минея общая с праздничной. М.: Печатный Авор, 1650; Ярославль, 2004. № 586.

${ }^{29}$ Евангелие. М.: Печатный Авор, 1628; Тверь, 2002. № 24.

30 Апостол. М.: Печатный Авор, 1621; Верхокамье, 2013. № 5.

${ }_{31}$ Минея скужебная, май. М.: Печатный Авор, 1626; МГУ, 2000. № 179.

32 В публикации А. С. Усачева выявлено 28 (из 733) записей XVI в., содержащих охранные формулы [Усачев]. Шесть относятся к 1530-1580-м гг. (по одной на Аесятилетие), 22 - к 1590-м гг.

${ }_{33}$ Славяно-русские рукописные книги XIV-XVI веков в хранилищах Тверской земли. Каталог. Тверь, 2012.

${ }^{34}$ Киримлические рукописи XV-XVII вв. в хранилищах Пермского края. Пермь, 2014.
} 
по 1662 г. ОАна запись сделана в XVIII в., но она не имеет точной даты. При этом большинство наиболее ранних записей содержат явные привязки к региону. Запись 1486 г. сделана в Вильно, 1549/1550 г. - в Новгороде, 1569 г. - в Тирасполе, 1569 г. - в районе Браслова (Белоруссия), 1631 г. - в Бельске, 1634 г. - в Брянске.

Таким образом, из шести наиболее ранних записей, имеющих привязку к региону, только одна (1549/1550 г.) сделана России (в Новгороде). Уже эта приблизительная статистика показывает, чтов большейстепенипрактикаохранных формулв XV-XVIвв. былараспространена в юрисдикции Киевской митрополии. Возможно, именно на западе православного мира она зародилась и затем перешла в Россию. Наиболее «мягкие» по своему содержанию формулы (из тех, чьи даты упомянуты выше) мы находим также в наиболее ранних записях. В 1486 г. виленский мещанин Андрей НозАрич писал: «...непорушно никим, а не поискивати тых Прелогов ни мне самому, а ни детем моим, а ни нашим ближним, а без нашее воли не Аавати тых Прелогов ${ }^{35}$. В 1549/1550 г. вкладчик в церковь Николы на Аипне отметил, что в скучае выноса книги змоумышиенник должен... каяться! Запись 1569 г., сАеланная в районе Тирасполя, содержит угрозу Страшного суда тому, кто нарушит запрет не выносить книгу из церкви. Запись 1631 г., сАеланная в Бельске, гласит, что книга от церкви «жадным способом никим отАана и отАалена быти не мает». Слово «прокмятие» содержится в записи 1633 г., сделанной на территории Белоруссии ${ }^{36}$, и в записи 1634 г., сАеланной жителем Брянска ${ }^{37}$. То есть самые категоричные формулы содержат записи, сделанные в 1630-е гг.

Примерно такую же статистику (в плане хронологии и географии распространения) Аают и материалы записей на старопечатных изданиях. При этом наиболее радикальные формулы на рукописях также встречаются в 1630-е гг.

\section{Хрономогия и география охранных формум}

В таблице 1 Приложения приведены данные по распространению охранных формул. Формат статьи не Аает возможности охарактеризовать каждое Аесятилетие отдельно. Отметим следующее.

Наибольшее количество Аатированных записей с охранными формулами приходится на 1630-е, 1640-е и 1650-е гг. Наиболее «массовыми» гоАами стали: 1635-й, 1643-й и 1654-й - на кажАый из них приходится по восемь записей с охранными формулами.

В 1630-е гг. выявлено наибольшее число Аатированных записей - их выявлено 39: 12 относятся к первом типу, 18 - ко второму, 9 - к третьему. Увеличилось и число регионов в этот периоА: 7 записей относятся к региону «Украина, Беморуссия, МолАавия», 5 - к РостовоЯрославскому и Московскому, 3 - к Северу, 2 - к Западному и Поволжью, 1 - к Черноземью. Итого семь регионов.

В 1650-е гг. наблюдается наибольший географический охват распространения записей с охранными формулами - Аевять регионов. Выявлена 31 запись: 11 - первого типа, 14 - второго, 6 - третьего. Из них 9 относятся к Ростово-Ярославскому региону, по три - к ВологодскоКостромскому и Черноземью, по Аве - к Московскому, Поволжью и региону «Украина, Белоруссия, Молдавия», по одной - к ВАадимиро-Суздальскому, Западному и Северному.

B XVIII-XIX вв. появление охранных формул носит единичный характер: выявлено 29 точно Аатированных записей (12 - первого типа, 6 - второго и 11 - третьего). Восемь относятся к Ростово-Ярославскому региону, пять - к региону «Украина, Белоруссия,

${ }^{35}$ Славяно-русские рукописные книги XIV-XVI веков в хранилищах Тверской земли. № 12.

${ }^{36}$ Киримлические рукописи XV-XVII вв. в хранилищах Пермского края. № 7.

${ }_{37}$ Славяно-русские рукописные книги XIV-XVI веков в хранилищах Тверской земли. № 81.

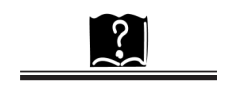


МолАавия», по четыре - к Западному и Московскому, три - к Черноземью, Аве - к ВятскоУральскому.

Примечательна последняя Аатированная запись с формулой: «Сию книгу се Евангилие жертвовалъ Иоилъ Авдеевъ Апраксинъ въ моленную деревни Андрикова въ память жены своей Евдокии Семеновны Апраксиной, преставившеися 1-го августа 1898 года, с темъ, чтобы никто (зачеркнуто) никемъ не былаприсвоена, не заложена инепродана, асчиталась бы собсвенностию моленной вечно. Въ томъ я и подписуюсь саморучно. Крестьянинъ деревни Анарикова Иоилъ Авдеевъ Апраксинъ. Аминь» ${ }^{38}$. Запись сделана старовером (видимо, по скучаю построения новой моленной в селе Анариково Закобякинского прихода Аюбимского уезда Ярославской губернии) на дониконовском изАании. Традиционализм, свойственный старообрядцам, привел к тому, что они воспроизводили охранные формулы как часть традиции, сложившейся еще во времена, предшествующие расколу.

\section{Заключение}

Традиция охранных формул перешиа в старопечатную книжную традицию из рукописной. Уже в XVI в. прослеживаются разные региональные традиции (более радикальные на Западе и более мягкие в Центральной России). ОАнако наиболее категоричные формулы, которые содержат перечисления возможных вин, угрозы, а также последующие санкции, скмадываются только к 1620-м гг. Если наибольшее число записей с охранными формулами приходится на 1630-е гг. (таблица 1 Приложения), то наибольшее количество регионов, в которых преАставлены эти записи, - на 1650-е гг. В XVIII в. традиция ослабевает, а в XIX в. формулы и вовсе выглядят как исключение, а не как часть существовавшей практики. Наибольшее распространение охранные формулы получили в юрисаикции Киевской митрополии (Украина, Белоруссия, Молдавия), где на них приходится 17,5 \% записей, наименьшее - в ВятскоПермском регионе $(0,7 \%)$.

\footnotetext{
${ }^{38}$ Новый завет с псалтырью. Вильно: Типография Братства Св. Ауха, ок. 1596; Ярославль, 2004. № 40.
} 


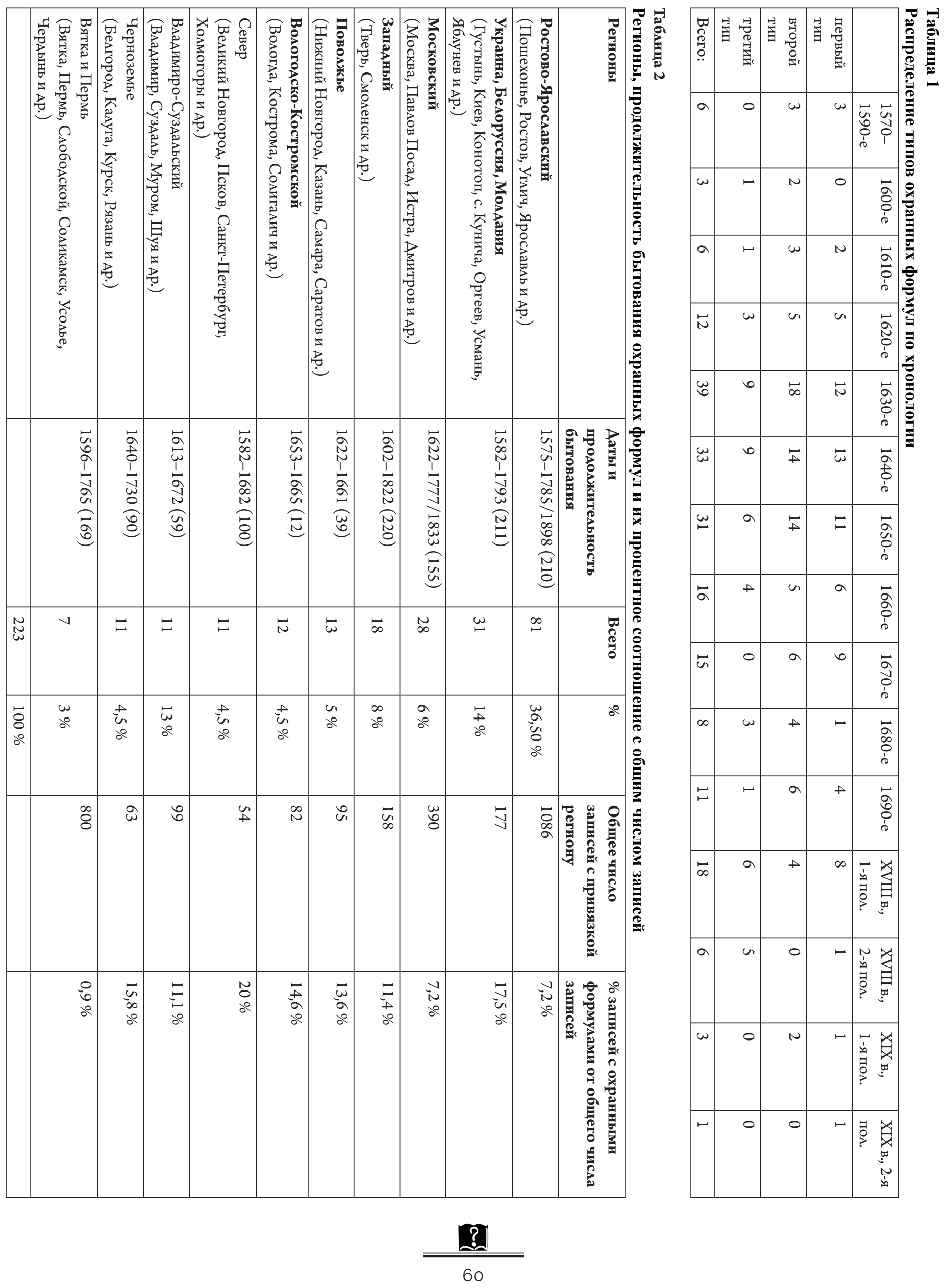




\begin{abstract}
Митература
Богданов В. П. Социальные аспекты бытования старопечатной киримлицы (по записям на экземпмярах Аониконовских изданий) // Вестник Московского университета. Сер. 8. История. 2012. № 1. С. 27-44. Богданов В. П., Высоикий Н. А. Записи на книгах старопечатной киримлицы XV-XVIII вв.: живые цифры Аля социальной истории // Эмектронный научно-образовательный журнал «История» [Электронный pecypc]. 2017. № 8. C. 11-20. URL: https://history.jes.su/s207987840001946-9-1 (Аата обращения: 20.05.2021). DOI 10.18254/S0001946-9-1

Каштанов С. М. Очерки русской Аипломатики. М., 1970. 498 с.

Поздеева И. В. Записи на старопечатных книгах кириммовского шрифта как исторический источник // Федоровские чтения. 1976. Читатель и книга. М., 1978. С. 39-54.

Поздеева И. В. Царь Алексей Михайлович, псковский помещик Василий Спякин и Аругие // Книга: Исследования и материалы. М., 1987. Сб. 55. С. 200-203.

Усачев А. С. Книгописание в России XVI века: по материалам датированных выходных записей. М.; СПб., 2018. Т. 1. 469, [2] с.; Т. 2. 524, [1] с., [8] А. цв. ил., факс.

Шапилова Е. В. Культурно-историческое значение вкмадных записей на экземплярах московских изАаний Евангелия XVII в. [Электронный ресурс]. URL: http://www.e-culture.ru/Articles/2007/Shapilova.pdf (Аата обращения: 20.05.2021).

Шустова Ю. Э. Записи в изАаниях типографии Аьвовского братства 1591-1644 годов из собрания научно-исследовательского отдела редких книг (Музея книги) РГБ // Вивлиотека: История книги и изучение книжных памятников. М., 2011. Вып. 2. С. 44-79.
\end{abstract}

\title{
References
}

Bogdanov, V. P. Sotsial'nye aspekty bytovaniya staropechatnoi kirillitsy (po zapisyam na ekzemplyarakh donikonovskikh izdanii) [Social Aspects of the Existence of the Old-Printed Cyrillic Books (According to the Inscriptions on Copies of pre-Nicon Publications)]. In Vestnik Moskovskogo universiteta. Ser. 8. Istoriya. 2012. No. 1. Pp. 27-44.

Bogdanov, V. P., Vysotskii, N. A. Zapisi na knigakh staropechatnoi kirillitsy XV-XVIII vv.: zhivye tsifry dlya sotsial'noi istorii [Inscriptions on the Early Cyrillic Books (15-18 Centuries)]. In Elektronnyi nauchnoobrazovatel'nyi zhurnal "Istoriya" [Electronic resource]. 2017. No. 8. Pp. 11-20. URL: https://history.jes.su/ s207987840001946-9-1 (accessed May 20, 2021). DOI 10.18254/S0001946-9-1

Kashtanov, S. M. Ocherki russkoi diplomatiki [Essays on Russian Diplomacy]. Moscow, 1970. 498 p. Pozdeeva, I. V.Zapisi na staropechatnykh knigakh kirillovskogo shrifta kak istoricheskii istochnik [Inscriptions on Old Printed Books of the Cyrillic Font as a Historical Source]. In Fedorovskie chteniya. 1976. Chitatel' i kniga. Moscow, 1978. Pp. 39-54.

Pozdeeva, I. V. Tsar' Aleksei Mikhailovich, pskovskii pomeshchik Vasilii Spyakin i drugie [Tsar Alexey Mikhailovich, Pskov Landowner Vasily Spyakin and Others]. In Kniga: Issledovaniya i materialy. Moscow, 1987. Issue 55. Pp. 200-203.

Shapilova, E. V. Kul'turno-istoricheskoe znachenie vkladnykh zapisei na ekzemplyarakh moskovskikh izdanii Evangeliya XVII v. [Cultural and Historical Significance of Contribution Inscriptions on Copies of Moscow Editions of the Gospel of the $17^{\text {th }}$ Century] [Electronic resource]. URL: http://www.e-culture. ru/Articles/2007/Shapilova.pdf (accessed May 20, 2021).

Shustova, Yu. E. Zapisi v izdaniyakh tipografii L'vovskogo bratstva 1591-1644 godov iz sobraniya nauchnoissledovatel'skogo otdela redkikh knig (Muzeya knigi) RGB [Inscriptions in the Publications of the Printing House of the Lviv Brotherhood of 1591-1644 from the Collection of the Research Department of Rare Books (Book Museum) of the Russian State Library]. In Vivlioteka: Istoriya knigi i izuchenie knizhnykh pamyatnikov. Moscow, 2011. Issue 2. Pp. 44-79.

Usachev, A. S. Knigopisanie v Rossii XVI veka: po materialam datirovannykh vykhodnykh zapisei [Book Writing in Russia of the $16^{\text {th }}$ Century: On the Materials of Dated Output Inscriptions]. Moscow; Saint Petersburg, 2018. Vol. 1. 469, [2] p.; Vol. 2. 524, [1] p., [8] 1. of coloured il., facs. 
Vladimir P. Bogdanov

Lomonosov Moscow State University, Moscow, Russia

\begin{abstract}
SECURITY FORMULAS OF THE 16th - 19th CENTURIES
ON EXEMPLARS OF OLD PRINTED CYRILLIC EDITIONS:

EVOLUTION AND CLASSIFICATION OF TEXTS
\end{abstract}

"Security formulas" as used by the author shall mean speech patterns that regulate the usage of books. These are the components of inscriptions that fix the contributions of books to churches or monasteries, as well as the facts of ownership of these monuments. The subject of the analysis is inscriptions on old printed books of the $16^{\text {th }}-18^{\text {th }}$ centuries. The author divided 334 inscriptions into three groups based on their content (from the most neutral, containing only phrases like "keep the book forever and no one will wear it out", to the most emotionally colored, having the words "anathema" and "cursed"). The author shows that the top (peak) of their usage falls on the 1630s, but individual inscriptions are found up to the end of the $19^{\text {th }}$ century.

Keywords: inscriptions on books, old printed Cyrillic editions, security formulas, churches, monasteries, ownership 